\title{
Character Education in Islamic Boarding School as a Medium to Prevent Student Radicalism
}

\author{
Haris Supratno \\ Universitas Negeri Surabaya \\ Surabaya, Indonesia \\ harisupratno@unesa.ac.id
}

\author{
Heny Subandiyah \\ Universitas Negeri Surabaya \\ Surabaya, Indonesia \\ henysubandiyah@unesa.ac.id
}

\author{
Resdianto Permata Raharjo \\ Universitas Negeri Surabaya \\ Surabaya, Indonesia \\ rezdyraharjo@gmail.com
}

\begin{abstract}
This study aims to find and describe the character education model for students studying in Islamic boarding school, East Java Province, as a medium to prevent radicalism. Empirically, Islamic boarding schools have a very strong culture in implementing character education through both formal and non-formal education. The formal education can be taught by discipline, cleanliness, obedience to the rules, respect for caregivers and teachers, the spirit of seeking knowledge, and simplicity. Meanwhile, the non-formal ones include discipline in congregational and midnight prayer, respect for caregivers or teachers, and respect for all people. By implementing such education model, all students' activities are very solid and always oriented on good and religious activities to avoid student radicalism behaviors including but not limited to thought, speech, and deeds. Character education has been applied in Islamic boarding schools for a long time period through students' daily habits and various good examples from their caregivers, coaches, and teachers in the form of behaviors, ethics, morals, and language speech. Such education can further be used as a medium to prevent student radicalism expressed in the form of words, thoughts and actions. This study contributes to the development of education based on character building applied in formal and non-formal education as well as in public schools and private schools.
\end{abstract}

Keywords-Character education; prevention; radicalism; students

\section{INTRODUCTION}

Islamic boarding school is a non-formal education institution and non-formal education that has strong cultural resilience and flexible education system that is able to adjust to every changes and development of the times [1]. The Islamic boarding school is one of the community-based educational models that are commonly established by the Muslim community which carries on the purpose to educate the students to understand and practice the Islamic teachings
[2]. The Islamic boarding school holds a very vital role to shape the moral guidance and empowerment as well as to develop the society, young generation in particular, because one of the characteristics of the Islamic boarding school is to perform the Islamic-based educational system. The boarding school can also in this case empower the society, the surrounding citizen in particular, either in the socio-cultural, religion or economic field [3-5].

The Islamic boarding school has long been applied the educational characters through several religion-based educational practices. Furthermore, the Islamic boarding school does not only apply religion-based educational practices, but Islamic boarding school also has developed a general educational system that based on the entrepreneurship in order to prepare the human resources that is able to follow the development of times and the development's needs. It will result that the Islamic boarding school doesn't only prepare the unemployment human resources, because they don't have needed competencies in term of industrial and working world [6-7].

Educational character is one strategic process to educate the nation's life and to prepare the qualified human resources, so that educational character should be professionally arranged [8]. Education character in the Islamic boarding school is intriguing and is able to shape the students' strong and independent character. Those characters can be the media to prevent the radicalism behavior in the particular Islamic boarding school. The radicalism problem either in Indonesia or abroad is usually administered to the Islamic religion and terrorism manner, because the radicalism perpetrators are commonly Islam adherents. The impression was getting stronger when the Bali's bomb perpetrators were revealed that they were Muslim and were graduated from the Islamic boarding school. That makes the radicalism and terrorism is 
administered to the Islamic practice and Islamic boarding school. Moreover, it is strengthened by the Wall Street bombing in the united states of America that happened on November 11th 2004. It was revealed that the perpetrators were Muslim. The event made Islam-phobia developed among American and European citizen. In addition, the radicalism has recently happened in the East Java. In Indonesia, there have been radicalism and terrorism practices which aimed several churches in Surabaya City.

In order to prevent the radicalism either in thought and behavior of the students, character education and multiculturalism is needed as its media. Character education is inseparable integral part of educational event. The education should cover the aspects of knowledge, attitude and skills. The attitude aspect is one of the important factors to shape attitude, ethic, moral, and manner which are now as known as the character education or simply called as mental revolution. The character education development holds a very vital role to younger generation that should be implanted within the early education time, either in formal education or non-formal education, including in the Islamic boarding school [9-10].

The education as the process of civilization should contain value or character education. The value or character education is the effort to help students to know and recognize how important an education is, and lives up appropriate values that can be the guidance or example of attitude and human behavior as an individual or as the member of society to live together. The character and personality education is integral part of the cultural education. The students' character and personality education can be shaped through family education and / or character education in the school. The character education as its first emergence takes an important role as the development education process because character education is formed and influenced by the environment [11-12]

The character education is very important to be applied in Indonesia. It is because the Indonesian character education has decreased and undergone several events that result on nation's disintegration and also result on society's ethic and moral decreasing that makes loss of nation's identity as the religious, adapting, dignified country [13]. Meanwhile, the education culture tends to be unready to be applied in the character education. The character education can be used as resources to shape younger generation' character that is anchored in the cultural and religious values [14-17].

The character education can increase the academic achievement. The religious behavior like the obedience to perform worship influences the patience, manner, honesty, craft, perseverance, unyielding attitude, independence, and responsibility. The honesty attitude and behavior influences someone's commitment. The behavior of respecting achievement, recognize and respect others' achievement influence someone's creativity. The patient attitude and behavior, courtesy, and respect for other people of different religions affect the character of peace and social care [18]. The scope of character education comes from religion, Pancasila (Five principles of Indonesian nation), culture, and national education goals which include: religious, honesty, tolerant, disciplined, hard work, creative, independent, democratic, curiosity, national spirit, love of the homeland, respect for achievement, friendly / communicative, love peace, love reading, caring environment, social care, and responsibility [19].

Islamic boarding school is a multicultural society because the students (santri) consist of various ethnic groups and different cultures. Although there are differences between them, they can still live side by side, respect and tolerate one another. However, lately in Indonesia, there has been a lot of violence in the name of Islam which is carried out by radicals, fundamentalists and terrorists [20].

Multicultural society is categorized into three categories, namely (1) phenomena of a community that show the existence of cultural diversity based on the sub-cultural characteristics of a society that is still within a cultural sphere, (2) cultural diversity based on the critical thoughts that develop in a society, and (3) cultural diversity based on the awareness of the different principles of beliefs and practices that exist in a more complex and pluralistic society. This plurality is one of the characteristics of the Indonesian that must be instilled are values of togetherness such as tolerance, respect for each other, and recognizing their own existence in order to be able to adapt to various cultural differences that aim to avoid conflict [21-22].

Character education in Islamic boarding schools is a model of mental revolution movement that can be used as a medium to prevent radicalism. The phenomenon of radicalism has begun recently to develop in various regions in Indonesia, America, Thailand, Burma and the Middle East. This phenomenon is increasingly prevalent in the lead up to the 2018 regional head elections and 2019 national leadership in the last five months, starting from January to May 2018. As a result, many conflicts and election violations occurred. The coordinator of Missing Persons and Violence (Kontras) has reported various types of election violations to the General Election Supervisory (Banwaslu). They found that there were about 387 violations committed by certain elements which resulted in political, economic, and social instability as well as inconvenience, peace and calm in the social life [23].

In America and Europe, radicalism is often associated with Islam, meaning that radicalism and terrorism are always Muslims; resulting Islam is often identified as conservatives or fundamentalists and terrorists, which raises the term Islam phobia there [24-26]. The Western view that Islam is a fundamentalist, fanatical and terrorist is getting stronger after the incident of World Trade Center in New York on September 11, 2001 [27]. Radicalism arises due to the feeling of disappointed or dissatisfied with the injustices, inequalities and oppression of a certain group [28-29]. For instance, in the Middle East, there are many Islamic civilizations that become the pride of Muslims were destroyed by the United States and its allies. As the result, a number of militant Muslims fight back in various ways, one of them is by committing acts of terrorism. Doing an open battle with America and its allies is impossible for the militant Muslims because of the differences 
in weapons, so they choose the path of terrorism to show their resistance.

Radicalism is an ideology that will change in revolutionary, comprehensive and fundamental without regard to the legislation, politics, social and religion. Radicalism can include thoughts, ideologies, and actions in the political, social and religious spheres [30]. Radicalism can occur everywhere in the world, in America, Europe, Asia, including Indonesia. Lately, it was found that a lot of radicalism and terrorism act has occurred in Indonesia, in Surabaya for instance. There were bombings in several churches and police stations which involved all family members ranging from father, mother and their children as the perpetrators of the bombing. This is seen as a new phenomenon because terrorists involve all family members including children in the act of bombing.

\section{METHOD}

This study used a qualitative research design due to the data obtained was presented empirically which prioritizes processes and results, and analyzes the data inductively. The data collection techniques used observation, interviews, recording, and field note. The data analysis techniques used descriptive analysis techniques and content analysis.

\section{RESULT AND DISCUSSION}

The character education in Islamic boarding schools is generally carried out through non-formal education and formal education because modern boarding schools in general have implemented non-formal education and formal education. Character education models in modern Islamic boarding schools in East Java generally have similarities through habits or culture and examples carried out by caregivers, kiai, ustad, and senior students. Islamic boarding schools have long applied the character education. However, in Islamic boarding schools, the term is better known as moral education [31].

The character education through non-formal education generally appears in the practice of habituation or culture, respect for older people, adherence of students to kiai, ustad, and caregivers, diligence in studying, evening prayers, discipline, simplicity, and the power of holding the existence of Islamic students culture.

The practice of habituation must be done by each student, such as every student must respect and do handshake and kiss hands when meeting caregivers, kiai, ustad, and senior students. The respect is such as bowing head and body, but not worshiping. This culture has deeply existed in Islamic boarding schools. Another example of habituation is the habit of waking up at night to perform tahajjud prayer. The students are accustomed to waking up at around 03.00 a.m. to perform tahajjud prayer together or individually. Together is prioritized. Queuing habits at breakfast, lunch or night is another example. The students at meal times are generally managed by caregivers. When eating, they must queue to get their rice or side dishes. Another important habit is the habit of praying together, especially Ashar, Mahrib, Isak, and Subuh prayers. Meanwhile, dhuhur prayer is done at school or on campus, because in the afternoon the activities are generally in formal schools or on campus.

Caregivers, kiai, and ustad gave examples to students in daily activities such as being simple, e.g. wearing sandals, wearing peci in both non-formal and formal activities. This way to dress up has been the habit, and even become one of the characteristics of Islamic boarding school students, namely wearing simple clothes, sarongs, peci and sandals. With this example, there is no competition in dressing in Islamic boarding schools. The way to dress is generally simple, both at the non-formal and formal activities. A very common feature of the students in both non-formal and formal activities is that the students always wear simple clothes and peci. The character education of the students also appears when obeying the caregivers, kiai, and ustad. The students in general were very obedient to caregivers, kiai, and ustad. They do not dare to do radicalism, both in the form of thoughts, words, especially actions that lead to radicalism. The students have been practicing the obedience and respect to older people, whoever and whatever their position and social status. The students' tawadhuk and konaah are the main characters.

The character education in the field of religion is also evident by the time of prayer. At the time of the call to pray, the students go immediately to queue up to take ablution water and pray together. The discipline of the students has been firmly embedded in their behavior. During the night the students were also used to waking up to do the midnight prayer, to get up early to perform morning prayers together. Discipline of the students to wake up at night to perform tahajjud prayers and early in the morning to perform morning prayers together have been long practiced and have become a habit in daily activities, so that these activities become the life in Islamic boarding schools [33].

The character education in formal and non-formal learning has also been embedded in the attitudes and behaviors of the students well and has become a routine activity or culture, such as waking up at night doing prayer, getting up early for morning prayer together, reciting the book after morning prayer, having breakfast, attending formal education activities from 7:00 a.m. to 1:00 p.m., even at the University until 4:00 p.m., having rest, praying ashar together, praying maghrib together, having dinner, reciting the Qur'an, praying together, and studying. The cycle of the activities has become the activities of the students and the culture of Islamic boarding schools in general.

Character building in simple life appears within the behaviors of Islamic boarding school students (santri), teachers (ustad), great teachers (kiai), and the caretakers. They live in simplicity including the way they dress and behave which are very prudish. For example, most students dress simply with unpretentious clothes having unpretentious quality, affordable price, inconspicuous color, and very simple style. The important one for them is that the clothes cover the body and they are clean. The male students always wear Islamic rimless cap and mostly they wear sarong and slippers for informal educational activities. [35]. 
Generally, the students have strong characters in preserving the existence of Islamic school (pesantren) culture. It can be seen from the way they dress. They use the same way of dressing by wearing Islamic rimless cap, sarong, and slippers for going to some certain places. However, when they have to attend formal educational activities, they cannot wear them. Instead, they must be formally and neatly dressed. Moreover, they are required to wear shoes, not slippers. It means that they do not need to be embarrassed of their identity as Islamic school students (santri). Because of the attributes they wear, in Indonesian society, especially in Java, those kind of students are called sarong community.

Big and modern Islamic schools commonly implement both formal and informal education systems so that the character building model is applied in both education systems. Such model of character building is implemented in elementary level up to higher level of education. The discipline rules for students implemented by Islamic boarding school prevail also for formal education starting from Islamic Elementary education (Madrasah Ibtidaiyah) until university level. Therefore, their character and discipline have been cultured in their deepest selves so that their characters will stay and will not change everywhere they go.

The character building model through formal education is done through implanting discipline like coming on time. The students follow the formal education by coming at 07.00 in the morning. They are not allowed to enter the class if they are late for more than 15 minutes without any clear reason. Being discipline has become the students' culture in formal education context. Through that way, the students will come to the class on time.

Every morning, before the class begins, the students are asked to pray dhuha together, led by the teachers in turn. Praying dhuha in formal education of Islamic boarding school has been a culture for the students. Before starting the teaching and learning process, they pray together to Allah SWT [36].

In formal education context, cleanness is implanted both inside and outside the classroom. The students are habituated to throw the rubbish into the rubbish bins that have been provided. They are also habituated to pick the rubbish they find and put it into the rubbish bin. Every day, when they meet their teachers, they have to greet them, shake their hands, and kiss their hands. They are also taught to be honest in every single matter every day. Speaking politely to others becomes another behavior that the students are taught to. They are habituated to always speak politely to everybody, including to their friends, school staffs, and also their teachers [37].

Generally, students in Islamic boarding school in East Java have good characters and attitudes so that there is no or only few radicalism behaviors in the form of utterances, ideas, and other forms of small radicalism behaviors. Radicalism is a behavior or activity done by a person or a group of people that excessively breaks the ethics, morality, religion, and even laws; in the form of utterances, ideas, or even behaviors. Radicalism in the form of ideas is like having an idea to replace Pancasila with another national ideology such as Islamic khilafah or an idea to replace the fundamental 1945 laws with any other laws. Another example is an idea to replace the president unconstitutionally. Based on the study that the researcher has done, there was not any Islamic boarding school student found who had any idea to replace the ideology of Indonesia with other ideology such as Islamic nation ideology, replace the 1945 fundamental laws, or replace the president unconstitutionally [38].

Radicalism in the form of oral, was also not found in Islamic boarding schools in East Java. In general, the students are prioritizing to use good and polite language when they speak. Their communication behavior among the school's members, school's fellows, kiai (school's leader), and teachers, is very respectful, smooth and polite manner. They used to be a passive when faced with these school's members, or they used to listen rather than speak.

Radicalism in the form of activities was also not found in Islamic boarding schools in East Java. In general, the student's activities are mostly directed to both religious and nonreligious activities, such as attending congregational prayer services, reciting Holy Qur'an, attending formal education at school or on campus, learning to be independent, eating and sleeping.

The students' activities at the boarding school are very tight and it is impossible to carry out radicalism activities, either in the form of thought, verbal, or deed. These activities generally lead to activities that are based on religion so that they will form the character of good students. Moreover, they have a strong belief and good morals, so that radicalism and terrorism in Islamic boarding schools can be prevented by the character education model that has been applied in boarding schools. Character education models in Islamic boarding schools have been very strong and can be used as a media to prevent radicalism and terrorism. [39]

Thus, the assumption that the Islamic boarding school is the basis of radicalism and terrorism education that is currently developing in the Western world is not true. Although there are members of terrorism which in reality are former students of the Islamic boarding school and Muslims, but it is not appropriate to be used as a generalized reason that Islamic boarding schools are centers of radicalism and terrorism education.

Islamic boarding school is actually a very strong center of religious education that produces human resources that have strong faith, noble character, broad-minded, respectful, and tolerant towards others, both Muslims and non-Muslims. This is because of the Islamic education taught that everyone is a brother who must be loved, respected and tolerant to each other [40].

\section{CONCLUSION}

Character education in Islamic boarding schools in East Java has long been applied well through non-formal education and formal education. This is because of the modern Islamic boarding schools have implemented two models of education, namely non-formal education and formal education from the Ibididaiyah level (Elementary level) to University level, 
especially large modern Islamic boarding schools. While, middle and small Islamic boarding schools one, generally, only carry out formal education from the Ibtidaiyah level to Madrasah Aliyah level (senior high school level).

Character education in the Islamic boarding school in East Java generally has almost the same pattern. Their pattern was through the applying of good habits or culture and exemplary behavior in non-formal education and formal education environment in Islamic boarding schools, such as respecting caregivers, kiai, teachers, and others, attending congregational prayers, tahajjud prayers (late night prayers), night prayers, reciting the book together, be humble, polite, study hard, discipline, cleanliness, simplicity.

Character education applied in formal education in the form of good examples that has been implemented in daily life and has become a culture in the formal school environment includes a discipline culture when coming to school, religious culture, congregational and noble prayers, spreading greetings to anyone, hand-shaking with teachers and kissing their hands, being humble, respect the teachers, being polite, being diligent in studying, and living a simple life.

Students' character education in Islamic boarding schools in East Java can be used as a medium to prevent student radicalism either in words, thoughts, ideologies, or actions. The students generally have good characters, obedience and respect to any older people such as caregivers and teachers. The current perspective that shows Islamic boarding school as a center of radicalism and terrorism remains untrue. Islamic boarding schools have long been a center of religious education which produces people with good character and morality.

\section{REFERENCES}

[1] Nasir, Ridwan. Tipologi Format Pendidikan Ideal. Yogyakarta : Pustaka Pelajar, 2005.

[2] Toriquddin, Moh, "Pemberdayaan Ekonomi di Pesantren Berbasis Syariah". Jurnal Syariah dan Hukum, Volume 3 Nomer 1, Juni 2011, Halaman 24-35.

[3] Sumardi, Kamin. "Potret Pendidikan Karakter Pondok Pesantren Salafiah". Jurnal Pendidikan Karakter, Tahun II, Nomer 3, Oktober 2012.

[4] Hidayat, Diyah Aji Jaya. "Pemberdayaan Penyesuaian Diri Santri di Pondok Pesantren Tradisional dan Modern". Jurnal Talenta Psikologi. Vol.1 No.2, Agustus 2012. pp.106-126.

[5] Sholeh."Persiapan Indonesia dalam Menghadapi AFC (asean economic community) 2015". Ejounal Ilmu Hubungan Internasional, Volume 1, Nomor 2. 2015, 509-522 (http://ejournal.hifisip-umul.ac.id. Diakse 19 April 2016)

[6] Supratno, Haris, Heny Subandiyah, Dedy Rahman Prehanto, dan Aris Dwiyanti, Pendidikan Kesehatan Lingkungan Berbasisi Karakter Pondok Pesantren di Jombang. Surabaya: Unesa University Press,2016.

[7] Anjana, Atim R, Melodi Terakhir Sang Muazin Subuh. Banten; Shuhuf Media Insani, 2011.

[8] Fatkuroji. 2014. "Kesiapan Pendidik dan Tenaga Kependidikan dalam Menyosong Masyarakat Ekonomi ASEAN". Jurnal Idorah, Vol.1,Juni, 101-114 (http://jurnal.raden fatah.ac.id. diakses 19 April 2016).

[9] Mu'in, Fatchul,Pendidikan Karakter, Konstruksi Teoritik \& Praktik. Jakarta : Ar-Ruzz Media,2011.

[10] Tilaar, H.A.R, Pendidikan untuk Masyarakat Indonesia Baru. Jakarta : Grasindo, 2002.

[11] Mu'in, Fatchul,Pendidikan Karakter, Konstruksi Teoritik \& Praktik. Jakarta : Ar-Ruzz Media,2011.
[12] Tilaar, H.A.R, Pendidikan untuk Masyarakat Indonesia Baru. Jakarta : Grasindo, 2002

[13] Chrisiana, Wanda, "Upaya Penerapan Pendidikan Karakter Bagi Mahasiswa (Studi Kasus di Jurusan Teknik Industri Uk Petra)". Jurnal Teknik Industri vol.7. No.1. Juni 2005, pp. 83-90 (http://jurnal imdustri.petra.ac.ad. 19 April 2016)

[14] Mu'in, Fatchul,Pendidikan Karakter, Konstruksi Teoritik \& Praktik. Jakarta : Ar-Ruzz Media,2011.

[15] Tilaar, H.A.R, Pendidikan untuk Masyarakat Indonesia Baru. Jakarta : Grasindo, 2002.

[16] Afandi , Rifki. 2011. "Integrasi Pendidikan Karakter dalam Pembelajaran IPS di Sekolah Dasar". Pedagogia. Vol.1, No. 1, Desember,211, pp. 85-98 (http://jurnalunsida.ac.id. Diakses 19 April 2016).

[17] Putri, Noviani Achmad. 2011. "Penanaman Nilai-Nilai Pendidikan Karakter Melalui Mata Pelajaran Sosiologi”. Jurnal Komunitas 3 (2), 2005-2015, 2011 (http://journal.unnes.ac.id./nju/index.php/komunitas. diakses 19 April 2016).

[18] Sucipto, "Model Pendidikan Karakter di SMA Negeri 1 Sidoarjo". Interaksi. Volume 01, Nomor 01. 1-7, 2013 (http://ejournal.unesa.ac.id. Diakses 19 April 2016).

[19] Zulnuraini, "Pendidikan Karakter: Konsep, Implementasi dan Pengembangannya di Sekolah Dasar di Kota Palu". Jurnal Dikdas, No 1, Vol. 1, September 2012. hlm. 1-10 (http://jurnal pgsd.untad.dot.com., diakses 19 April 2016)

[20] Muliadi, Erlan, "Urgensi Pembelajaran Pendidikan Agama Islam Berbasis Multikultural di Sekolah”. Jurnal Pndidikan Islam. Volume 1.Nomor 1.2012, pp. 55-68.

[21] Taufik, Ahmad, 2014. "Multicultural Literature: The Identity Construction in Indonesian novels". Humaniora. Volume 26. Nomor 1. Februari. 22-31.

[22] Arifudin, Iis. 2007. "Urgensi Implementasi Pendidikan Multikultural di Sekolah", ”Jurnal Pemikiran Alternatif Pendidikan. Volume 12. Nomor 2, Mei-Agustus, 2007, pp. 1-9.

[23] Jawa Pos, Sabtu, 23 Juni 2018, hlm.1.

[24] Yusof, Kamaruzaman, Iran Herman, Baddlihisham Mohd Nasir,"Islamic Radicalism in Malaysia: an overview". Procedia Social and Behavioral Sciences 5(2010) 2119-2125.p. 2119-2125.

[25] Lauriola, Marco, Renato Foschi, Luca Marchegiani. 2015. "Integrating values and cognitive style in model right-wing radicalism". Personality and Individual Differences. 2015. Pp.147-153.

[26] Kim, Dae Soon, "The rice of European right radicalism: The case of Jobbik". Communist and Post-Communist Studies,2016.pp. 345-357.

[27] Yusof, Kamaruzaman, Iran Herman, Baddlihisham Mohd Nasir,"Islamic Radicalism in Malaysia: an overview". Procedia Social and Behavioral Sciences 5(2010) 2119-2125.p. 2119-2125.

[28] Soliman, Abdrabo, Tarek Bellaj, Maher Khelifa. 2016. "An integrative psychologigal model for radicalism: Evidence from structural equation modeling". Personality and Individual Differences. 127-133.

[29] Fedotova, Olga," Radicalism and Terrorism Problems in a Scientific Discourse of Rucian Social Sciences", Procedia Social and Behavioral Sciences 5(2010) 2119-2125,2013, pp. 334 -343.

[30] Sesmiarni, Zulfani, "Membendung Radikalisme Dalam Dunia Pendidikan Melalui Pendekatan Brain Base Leraning". Kalam, Volume 9, N0mor 2, Desember 2015, 233-252..

[31] Hasil wawancara dengan Hamid, Rektor Universitas Nurul Jadid, Paiton, Probolinggo, tanggal 9Mei 2018, di Kampus Universitas Nurul Jadid, Paiton, Probolinggo

[32] Hasil wawancara dengan Jauharul Afif, Pengurus dan Ustad Pondok Pesanren Denayar Jombang, tanggal 29 Mei 2018, di Pondok Pesantren Denayar Jombang

[33] Hasil pengamatan partisipan, selama tahun 2015-2017 di pondok pesantren di Jombang.

[34] Hasil pengamatan partisipan, selama tahun 2015-2017 di pondok pesantren di Jombang.

[35] Hasil pengamatan partisipan, selama tahun 2015-2017 di pondok pesantren di Jombang. 
[36] Hasil pengamatan partisipan, selama tahun 2015-2017 di pondok pesantren di Jombang.

[37] Hasil wawancara dengan Hamid, Rektor Universitas Nurul Jadid, Paiton, Probolinggo, tanggal 9 Mei 2018, di Kampus Universitas Nurul Jadid, Paiton, Probolinggo.

[38] [38] Hasil wawancara dengan Jauharul Afif, Pengurus dan Ustad Pondok Pesanren Mambau"ul Ma'Arif Denayar Jombang, tanggal 29 Mei 2018, di Pondok Pesantren Denayar Jombang

[39] Hasil wawancara dengan K.H. Zuhri , Pengasuh Pondok Pesantren Nurul Jadid, Paiton, Probolinggo, tanggal 9 Mei 2018, di Pondok Nurul Jadid, Paiton, Probolinggo.

[40] Hasil wawancara dengan K.H. Imam, Pengasuh Pondok Pesanren Mamba"ul Ma'arif Denayar Jombang, tanggal 29 Mei 2018, di Pondok Pesantren Denayar Jombang. 